\title{
CUSTOMIZING LIABILITY RULES IN THE FEDERAL EMPLOYEES HEALTH BENEFITS PROGRAM
}

\section{INTRODUCTION}

Many criticisms are leveled against the current medical malpractice liability system. One school of thought for improving the system, well represented in this symposium, would encourage providers and customers to enter into contracts that reform malpractice liability rules. Among the many possibilities, such contracts might require arbitration of malpractice disputes, change the standard of care used to determine provider negligence, limit malpractice awards to victims' economic losses, or implement a "no-fault" compensation scheme. This note focuses on how an initiative might be developed specifically to permit private reforms of malpractice liability rules within the Federal Employees Health Benefits Program (FEHBP). ${ }^{1}$ Such an initiative by the federal government might favorably affect the cost of the FEHBP while at the same time encourage progress down a promising avenue toward reform of the tort system.

Under the FEHBP, the federal government maintains a "menu" of private health benefits plans in which federal employees may choose to enroll. ${ }^{2}$ These health benefits plans provide various combinations of health insurance and services ${ }^{3}$ and are operated by carriers in accordance with contracts with the Office of Personnel Management (OPM), ${ }^{4}$ the agency entrusted with

Copyright (C) 1986 by Law and Contemporary Problems

1. 5 U.S.C. $\$ \S 8901-8913$ (1982).

2. Actually, a federal retiree (annuitant) as well as a federal employee may participate in health benefits plans, and both may participate either as individuals or for self and family. See 5 U.S.C. $\S 8905$ (1982); see also 5 U.S.C. $\$ 8901$ (1) (1982) (definition of "employee"); 5 U.S.C. § 8901(3) (1982) (definition of "annuitant"); 5 U.S.C. $\$ 8901$ (5) (1982) (definition of "member of family"). Federal employees participate in a health benefits plan by "enroll[ing]" in that plan. 5 U.S.C. $\$ 8905$ (a) (1982). Annuitants "may continue [their] enrollment" in a health benefits plan. 5 U.S.C. \& 8905(b) (1982).

During an "open season" held in November and December each year, federal employees may enroll in health benefits plans, and federal employees and annuitants may change from one plan to another or from self to self and family. See 5 C.F.R. $\$ 890.301$ (d) (1984) (authorized by 5 U.S.C. $\$ 8913$ (b) (1982)). Federal employees may change plans under other circumstances as well. See 5 C.F.R. $\$ 890.301$ (1984) (authorized by 5 U.S.C. $\$ 8913$ (b) (1982)).

3. See 5 U.S.C. $\$ 8903$ (1982). The types of carriers that participate in the FEHBP and the nature of the plans that they offer are considered infra at notes 73-85 and accompanying text.

4. See 5 U.S.C. $\$ 8902(1982)$. These contracts extend for one year. As a result, each year the OPM reviews the benefits and premiums of plans in the FEHBP and negotiates adjustments. U.S. 
approving plans and running the FEHBP. ${ }^{5}$ Federal employees find it worthwhile to participate in the program because the federal government contributes a substantial predetermined amount toward any particular plan's subscription charge. ${ }^{6}$ Since the amount generally does not vary from plan to plan, federal employees have an incentive to shop among plans with price differences in mind and carriers offering plans have an incentive to compete in order to attract federal employees. Because of the competitive atmosphere of the FEHBP, the program has been cited as a potentially useful model for a system of national health insurance based on consumer choice and competition. ${ }^{7}$

The competitive atmosphere of the FEHBP also makes the program a potentially worthwhile arena in which to encourage private reform of malpractice liability rules. From the consumer's standpoint, the current liability system operates as a kind of mandatory insurance system that provides only limited financial protection at a very high cost. Although it may generate desirable incentives for providers to prevent negligent injuries, it may also encourage the practice of costly defensive medicine. As a result, some federal employees choosing among FEHBP plans might well be interested in choosing a plan featuring different liability rules. Conversely, some carriers might be interested in catering to the preferences of such federal employees and in using the latter's concessions on the liability front to attract providers' participation in the plan on favorable terms.

Customization of liability rules within the FEHBP might be facilitated either by federal legislation or by OPM regulations. The object of either approach would be explicitly to authorize a carrier to offer a health benefits plan in which a provider's potential liability to an enrolled subscriber in the event of a treatment-induced injury differs in some way from that prescribed by tort doctrine. The OPM, which must approve all FEHBP plans, ${ }^{8}$ could require such a customized-liability plan to meet certain safeguards designed to protect enrollees.

Interest in having the federal government lend a hand in improving the malpractice liability system already has been demonstrated in the Moore-

Office of Personnel Management, 1985 Enrollment Information Guide and Plan Comparison Chart 2 (1984). A federal employee or annuitant participating in a plan need not re-enroll each year, however; once he is participating in a plan, he remains in that plan until he switches to a different plan or drops out of the FEHBP. Id.

5. See 5 U.S.C. $\$ 8913(\mathrm{a})$ (1982) ("The Office of Personnel Management may prescribe regulations necessary to carry out this chapter.").

6. The contribution for any participating federal employee or annuitant is equal to $60 \%$ of the average of the premiums of the six largest health benefits plans, so long as that figure does not exceed $75 \%$ of the premiums for any particular plan. 5 U.S.C. $\$ 8906$ (1982). Employees and annuitants, however, must bear the full cost of deductibles, copayments, office visits, examinations, laboratory tests, and other similar expenses. Federal Employees Health Benefits Program, 1985 Enrollment Information Guide and Plan Comparison, at Chart 3 (pamphlet).

7. A. Enthoven, Health Plan: The Only Practical Solution to the Soaring Cost of Medical Care 82-84 (1980).

8. See supra note 5 . 
Gephardt bill, ${ }^{9}$ which is currently before Congress. Instead of facilitating private reform, however, this bill would impose a specific reform of liability rules. ${ }^{10}$ Nevertheless, there are several reasons why the private-reform approach is superior. ${ }^{11}$ First, because there is considerable uncertainty as to the effect and desirability of any particular reform, encouraging private initiatives would allow expression of differing preferences and would provide valuable information to guide future reforms. Second, although any change in liability rules is bound to place some consumers in a less advantageous position, most consumers would find an increased risk that was attributable to their personal choice more acceptable than a risk created by government action. Third, with a mandatory rule change, there is no incentive for providers to pass on savings attributable to the change; in contrast, if reform is left to private choice, providers might offer concessions to consumers to induce their agreement to a particular measure. ${ }^{12}$ Finally, and most important, any federal action embracing a specific modification of tort law would simply confirm the prevailing impression that government is the only legitimate source of malpractice reform. ${ }^{13}$ By the same token, federal action specifically endorsing private reform would be a clear invitation to the private sector to experiment.

Although conceptually superior to the Moore-Gephardt bill, the FEHBP initiative recommended in this note raises several major issues. One issue is whether any legislative or other change in the FEHBP is needed in order to permit carriers to offer customized-liability plans. A related issue is whether,

9. H.R. 5400, 98th Cong., 2d Sess. (1984)(introduced by Senators Moore and Gephardt). Senator Durenberger has introduced the same bill to the Senate. S. 2690, 98th Cong.. 2d Sess. (1984). These bills are an adaptation of ideas presented by Professor Jeffrey O'Connell. See O'Connell, Offers that Can't be Refused: Foreclosure of Personal Injury Claims by Defendants' Prompt Tender of Claimants' Net Economic Losses, 77 Nw. U.L. Rev. 589 (1982). The Moore-Gephardt bill was slightly modified and reintroduced in the first session of the 99th Congress as H.R. 3084, 99th Cong., lst Sess. (1985).

10. In the case of a malpractice claim arising from the provision of health care pursuant to any federal program, defendants named in the claim could foreclose that claim by tendering (within six months of the date of the injury involved) the plaintiff's net economic loss plus attorney's fees. H.R. 3084, 99th Cong., 1st Sess. (1985).

11. One reason the private reform approach is superior that is not discussed in the text, is that federal action permitting private reform probably would be less vulnerable to constitutional attack than federal action that imposes a specific reform. State statutes altering aspects of the malpractice liability system have been attacked, sometimes successfully, by individuals arguing that the statutes violated federal and state constitutional provisions. See generally Annot., 80 A.L.R. 3D 583 (1977). In contrast, Flagg Bros. v. Brooks, 436 U.S. 149 (1978), indicates that legislation that merely permits private reform of liability rules is not state action upon which a constitutional violation may be based. See generally J. Nowak, R. Rotunda \& J. Young, Constitutional Law 497-502 (2d ed. 1983) (state action is a necessary element of nearly all constitutional violations). In Flagg, the Supreme Court held that a state statute could permit a warehouseman to enforce his lien on goods by selling the goods, even if the state itself could not constitutionally sell the goods: "This Court . . . has never held that a State's mere acquiescence in a private action converts that action into that of the State." 436 U.S. at $164-67$.

12. See infra note 85 and accompanying text.

13. Such a result is not unlikely since the federal government traditionally has inhibited all types of health care reform by maintaining a continued presence in the health care sector as regulator, major purchaser, and indecisive architect. See C. Havighurst, Deregulating the Health Care INDUSTRY 387 (1982). 
assuming that some enabling action is needed, new OPM regulations would be as effective in facilitating change as federal legislation. Both of these issues are discussed in section II. Section III considers what safeguards would be appropriate to protect federal employees who are offered the option of enrolling in customized-liability plans. Section IV then outlines certain practical problems that might impede private reform of liability rules within the FEHBP, assuming that such reform is permitted. Finally, section V examines how a consumer choice approach to malpractice reform might be extended to other federal health programs including Medicare, ${ }^{14}$ the Civilian Health and Medical Program of the Uniformed Services (CHAMPUS), ${ }^{15}$ and the Health Maintenance Organization Act. ${ }^{16}$

\section{The Need to Change the FEHBP}

Neither the FEHBP statute nor the OPM's implementing regulations expressly permits or prohibits health benefits plans from altering malpractice liability rules. ${ }^{17}$ As a result, one may question whether an initiative in the form of legislation or new regulations is needed to permit such reform. Could not the OPM permit private reform simply by approving customizedliability plans? One reason why legislation or new regulations might be needed is to ensure that provisions altering liability rules are enforceable. Part A below considers the enforceability of such provisions under current law. Part B considers whether, if desirable private reforms are currently unenforceable, OPM regulations would be as effective as federal legislation in curing this defect.

Regardless of the enforceability of private reforms and the technical force of OPM regulations, however, the best argument for legislation may be the need for Congress to signal its desire to foster privately initiated change. Without such a signal, not much in the way of private reform is likely to happen in the near future. ${ }^{18}$

A. Enforceability of Private Reforms in the Absence of a Federal Initiative

1. State Law. Within the context of state law, the enforceability of only certain types of private reforms has been addressed. These include arbitration clauses, exculpatory clauses that purport to relieve providers of

14. 42 U.S.C. $\$$ 1395-1395zz (1982 \& Supp. I 1983).

15. 10 U.S.C. $\S \S 1071-1093$ (1982 \& Supp. II 1984).

16. 42 U.S.C. $\$ \S 300 \mathrm{e}$ to $300 \mathrm{e}-17$ (1982).

17. The FEHBP statute empowers the OPM to prescribe "reasonable minimum standards" for carriers and health benefits plans. See 5 U.S.C. \$ 8902(e) (1982). Nowhere in the OPM's implementing regulations are there specific prohibitions against plans containing clauses altering malpractice liability rules. Such restrictions could be imposed by the OPM, however, since the agency has reserved considerable general discretion for itself over the content of the health benefits plans. See 5 C.F.R. $\$ 890.203$ (1985).

18. See C. Havighurst, supra note 13 , at 387 . 
virtually all liability, absolute dollar limits on liability, and short time limits for making claims.

Agreements between providers and consumers to arbitrate malpractice claims have usually been enforced. ${ }^{19}$ Exceptions have arisen when circumstances indicated that an arbitration agreement was an adhesion contract in which a provider took advantage of his superior position or bargaining strength. Thus, plaintiffs have been allowed to avoid arbitration when the provision was inconspicuous, ${ }^{20}$ was not clearly worded, ${ }^{21}$ or did not bind both parties equally. ${ }^{22}$ Although courts have generally enforced malpractice arbitration clauses, a leading case upholding such a clause, Madden $v$. Kaiser Foundation Hospitals, ${ }^{23}$ suggests that other reforms may not be equally well received. ${ }^{24}$ In rejecting an argument that a contract containing an arbitration provision was an unfair adhesion contract, the California Supreme Court expressly relied upon the fact that an arbitration clause changes only the forum for dispute resolution and does not force a consumer to waive any "substantive right." 25

In contrast to the general acceptance of agreements to arbitrate malpractice claims, state courts have uniformly held invalid clauses that attempted to relieve a provider of all liability for malpractice. ${ }^{26}$ These cases reflect two concerns with such provisions. The first concern is that such contracts are adhesive and not fairly bargained. Thus, one court emphasized that the exculpatory clause was inconspicuous, ${ }^{27}$ while other courts have stressed that the consumer was presented with the contract just before he was to receive services and that his signature was a prerequisite to receiving services. ${ }^{28}$

19. See Madden v. Kaiser Found. Hosps., 17 Cal. 3d 699, 552 P.2d 1178, 131 Cal. Rptr. 882 (1976); Doyle v. Giulicucci, 62 Cal. 2d 606, 401 P.2d 1, 43 Cal. Rptr. 697 (1965); Cal. Civ. Proc. Code $\S 1295$ (West 1982); Мıсн. Comp. Laws AnN. $\$ \$ 600.5041-.5042$ (Supp. 1985). But see O’Keefe v. South Shore Internal Medicine Assoc., 102 Misc. 2d 59, 422 N.Y.S.2d 828 (1979) (court would wait for legislature to address enforceabiltiy of malpractice arbitration clauses). The state statutes cited above that authorize agreements to arbitrate malpractice claims, however, may impose notice requirements more stringent than those in the FEHBP. See infra notes 53-60 and accompanying text. In one case, an FEHBP health benefits plan with an arbitration provision, see infra note $\mathbf{5 5}$ and accompanying text, was subject to such a state statute; the plan's arbitration provision was upheld, however, since it comported with the state statute. See Dinong v. Superior Court, 102 Cal. App. 3d 845, 162 Cal. Rptr. 606 (1980). The case was decided before the FEHBP preemption statute was passed. See generally infra note 32 and accompanying text.

20. See Wheeler v. St. Joseph Hosp., 63 Cal. App. 3d 345, 133 Cal. Rptr. 775 (1976).

21. See id.

22. See Beynon v. Garden Grove Medical Group, 100 Cal. App. 3d 698, 161 Cal. Rptr. 146 (1980).

23. 17 Cal. 3d 699, 552 P.2d 1178,131 Cal. Rptr. 882 (1976).

24. Id. at 712,552 P.2d at 1186,131 Cal. Rptr. at 890.

25. Id.

26. See Tunkl v. Regents of the Univ. of Cal., 60 Cal. 2d 92, 383 P.2d 441, 32 Cal. Rptr. 33 (1963); Emory Univ. v. Porubiansky, 248 Ga. 391, 282 S.E.2d 903 (1981); Smith v. Hospital Auth., 160 Ga. App. 387, 287 S.E.2d 99 (1981); Meiman v. Rehabilitation Center, Inc., 444 S.W.2d 78 (Ky. 1969); Olson v. Molzen, 558 S.W.2d 429 (Tenn. 1977).

27. See Smith v. Hospital Auth., 160 Ga. App. 387, 389, 287 S.E.2d 99, 101 (1981).

28. See Tunkl v. Regents of the Univ. of Cal., 60 Cal. 2d 92, 98-101, 383 P.2d 441, 444-47, 32 Cal. Rptr. 33, 36-39 (1963); Smith v. Hospital Auth., 160 Ga. App. 387, 390, 287 S.E.2d 99, 102 
The second objection to exculpatory clauses is that they are against public policy because providers are subject to state regulation and hold themselves out as experts. ${ }^{29}$ This same concern led another court to hold invalid an agreement that limited a physician's liability to $\$ 15,000$ and required a malpractice victim to present his claim within thirty days of the medical service. ${ }^{30}$ The rationale behind the public policy argument appears to be that providers, because of their superior knowledge as experts, should be subject to the incentives to avoid adverse outcomes that are implicit in the liability system. ${ }^{31}$

Private reforms of malpractice liability rules need not take the form of complete exoneration of providers, and it seems quite possible that they might be designed and negotiated in ways that directly alleviate the concerns present in the exculpatory clause cases. Nevertheless, it remains true that none of the state law cases considered in this section directly supports the enforceability of private agreements that alter malpractice liability rules in ways other than by requiring arbitration of malpractice claims.

2. Federal Preemption. Despite doubts about the enforceability of contractual reforms under state law, one might inquire whether a customized-liability plan adopted by the OPM under the FEHBP would have the force of federal law and thus preempt inconsistent state law. One argument for preemption would be based on the following provision contained in the FEHBP statute:

The provisions of any contract [between the OPM and a carrier] under this chapter which relate to the nature or extent of coverage or benefits (including payments with respect to benefits) shall supersede and preempt any State or local law, or any regulation issued thereunder, which relates to health insurance or plans to the extent that such law or regulation is inconsistent with such contractual provisions. ${ }^{32}$

The obvious question is whether a plan provision affecting tort liability "relate[s] to the nature or extent of coverage or benefits (including payments with respect to benefits)" under the plan. A provision in a plan altering liability rules arguably satisfies this condition if federal employees enrolled in the plan received a price break or broader services in exchange for agreeing to the provision. The legislative history of the preemption statute, however,

(1981); Meiman v. Rehabilitation Center, Inc., 444 S.W.2d 78, 79-80 (Ky. 1969); Olson v. Molzen, 558 S.W.2d 429, 432 (Tenn. 1977).

29. See Tunkl v. Regents of the Univ. of Cal. 60 Cal. 2d 92, 102, 383 P.2d 441, 447, 32 Cal. Rptr. 33, 38 (1963); Emory Univ. v. Porubiansky, 248 Ga. 391, 394, 282 S.E.2d 903, 905 (1981); Smith v. Hospital Auth., 160 Ga. App. 387, 390, 287 S.E.2d 99, 102 (1981); Meiman v. Rehabilitation Center, Inc., 444 S.W.2d 78, 80 (Ky. 1969); Olson v. Molzen, 558 S.W.2d 429, 431 (Tenn. 1977).

30. See Tatham v. Hoke, 469 F. Supp. 914 (W.D.N.C. 1979) (applying North Carolina law), affd mem. sub. nom. Hoke v. Cappel, 622 F.2d 584 (4th Cir. 1980).

31. Cf. Defensive Medicine and Medical Malpractice: Hearing Before the Senate Comm. on Labor and Human Resources, 95th Cong., 2d Sess. 21 (1978) (Statement of Clark C. Havighurst, Professor of Law, Duke University) ("Almost certainly the reluctance of legislatures to make substantial changes in the law of medical malpractice has been attributable to a sense that patients should not be deprived of [the] basic right to seek redress for the serious harms that providers do, sometimes through culpable neglect.").

32. 5 U.S.C. $\$ 8902(\mathrm{~m})(1)(1982)$. 
militates against such a broad interpretation. ${ }^{33}$ The preemption statute was enacted specifically in response to state statutes and regulations that require health insurers to provide certain types and amounts of coverage and benefits regardless of the insurer's contract with the OPM. ${ }^{34}$ Provisions affecting liability rules between providers and federal employees would have no comparable direct effect on the types and amounts of coverage or benefits offered by a carrier.

Another argument for preemption is that federal law should be used to determine the enforceability of an FEHBP plan's liability provision in order to promote the federal government's interest in uniform benefits for its employees. A Tenth Circuit case, Howard v. Group Hospital Service, ${ }^{35}$ suggests, however, that this argument would fail. In Howard, a federal employee who had enrolled in a Blue Cross-Blue Shield plan brought suit against the carrier for refusing to pay for services received on the ground that they were not medically necessary, a condition for payment specified in the plan. The court, confronted with the issue whether the case presented a federal question, addressed the issue of federal preemption. Since the medical necessity provision of the plan did not conflict with applicable state law, the FEHBP preemption statute did not apply. ${ }^{36}$ The defendant nevertheless argued that, because the government was a party to the contract creating the plan, federal law should be used to interpret the provision at issue in order to promote uniformity of decisions. ${ }^{37}$ The Tenth Circuit held that the federal government's interest in the controversy was not substantial and thus that a uniform rule was not necessary. ${ }^{38}$ The court observed that the federal treasury would not be directly affected by the outcome of the case, that only private litigants were involved, and that the Blue Cross-Blue Shield plan would not be significantly hindered in its operation even though varying state law interpretations of "medical necessity" would affect which claims the carrier had to pay. ${ }^{39}$

Litigation over a customized-liability plan would present a similar situation. The government would not suffer any direct financial loss. The dispute would be between private litigants. Finally, it is unlikely that the carrier offering such a plan would be significantly hindered if the provision were subject to varying state interpretations. Malpractice liability of providers has no direct effect on a carrier's ability to underwrite services or to reimburse for normal health care costs.

33. See S. Rep. No. 903, 95th Cong. 2d Sess., reprinted in 1978 U.S. Code Cong. \& Ad. News 1413; H.R. REP. No. 282, 95th Cong. Ist Sess. (1977).

34. See, e.g., Mass. Ann. Laws ch. 175, §47B (Michie/Law. Co-op. 1977); Cal. Ins. Code, $\S 10176$ (West 1972); N.Y. INS. Law $\S 3221$ (McKinney 1985).

35. 739 F.2d 1508 (10th Cir. 1984).

36. Id. at 1510 n. 1 .

37. Id. at 1509 .

38. Id. (citing Clearfield Trust Co. v. United States, 318 U.S. 363 (1943)).

39. Howard v. Group Hosp. Serv. 739 F.2d at 1509-10. 
Even if a customized-liability provision in an FEHBP plan preempted inconsistent state law, which is unlikely, the provision is not necessarily enforceable. In the absence of a specific statutory directive, or an interpretation of a statute by an agency entrusted with its execution, preemption raises the question of how federal common law applies to the issue. ${ }^{40}$ There do not appear to be any federal common law cases on the enforceability of customized-liability provisions relating to medical malpractice. Nevertheless, the prospects of enforceability are probably just as doubtful under federal common law, which usually looks to state law for rules of decision. ${ }^{41}$

\section{B. Preemption by Federal Legislation or OPM Regulation}

Congress, of course, could override any state law that prevents FEHBP plans from effectively varying malpractice liability rules. ${ }^{42}$ Whether the OPM could accomplish this same feat through its power to issue regulations implementing the FEHBP is not as clear. Two related but distinguishable issues are involved. The first is whether the OPM has statutory authority to approve contracts with customized-liability provisions and to declare them legally enforceable. The second issue is whether such action by the OPM would override state law objections to such provisions.

Acceptance of private reforms and declaration of their enforceability do not appear to be outside of the OPM's statutory authority. In general, a construction of a statutory mandate by an agency entrusted with carrying it out is deferred to so long as the construction is reasonable. ${ }^{43}$ The OPM has

40. See American Nat'l Bank v. FDIC, 710 F.2d 1528, 1534 n.7 (1 l th Cir. 1983) ("Though it is settled beyond question that Federal law governs cases involving the rights of the FDIC, . . . courts must look to federal common law where, as in the present case, federal statutory law does not provide a rule of decision."); Woodfork v. Marino Cooks \& Stewards Union, 642 F.2d 966, 972-73 (5th Cir. 1981) (the fact that Employment Retirement and Income Security Act (ERISA) preempts state law regarding employee pension plans does not limit plaintiff-employees' remedies to the substantive provisions of the statute; as a result, federal common law would be applied); Murphy v. Heppenstall Co., 635 F.2d 233, 237 (3d Cir. 1980), cert. denied, 454 U.S. 1142 (1982) (although ERISA supersedes state law relating to employee pension plans, plaintiff-employees were not precluded from pursuing claims based on federal common law of labor-management relations and pension plans); Southern Pac. Transp. Co. v. United States, 462 F. Supp. 1193, 1198 (E.D. Cal. 1978) (when an issue is governed by federal law but not addressed by the federal constitution or a federal statute, federal common law applies); $c f$. Textile Workers Union v. Lincoln Mills, 353 U.S. 448, 456 57 (1957) (collective bargaining agreements are subject to federal law, not state law; this federal law must be fashioned by the federal courts).

41. See Textile Workers Union v. Lincoln Mills, 353 U.S. 448, 457 (1957) (in fashioning federal common law to govern collective bargaining agreements, state law would be looked to for guidance); American Nat'l Bank v. FDIC, 710 F.2d 1528, 1534 n.7 (11th Cir. 1983) (although only federal law applies to cases involving the rights of the FDIC, the court would look to Florida law to provide the rules of decision for analyzing an escrow agreement that the parties assumed would be controlled by Florida law); Southern Pac. Transp. Co. v. United States, 462 F. Supp. 1193, 1198 (E.D. Cal. 1978) (a federal common law rule of decision can derive from state law).

42. See generally J. Nowak, R. Rotunda \& J. Younc, supra note 11, at 292-93. To absolutely assure preemption, Congress could specifically provide that its legislation preempted state law.

43. Chevron, U.S.A., Inc. v. Natural Resources Defense Council, Inc., 467 U.S. 837, 842-45 (1984). 
authority to enter into contracts with carriers ${ }^{44}$ and general authority to carry out the FEHBP. ${ }^{45}$ It would seem entirely reasonable for it to declare that providers and federal employees are bound by plan provisions affecting tort rights despite inconsistent state law or policy. As discussed further below, the OPM might specify certain conditions that must be satisfied before federal policy would require enforcement of the contract's terms; such conditions might be aimed at satisfying concerns similar to those that might prompt state courts to deny enforcement.

Whether issuance of such a regulation would preempt inconsistent state law is not perfectly clear. Nevertheless, if the OPM has statutory authority to declare federal policy, then that policy would seem to be binding on the states. The true issue, therefore, remains whether Congress meant to allow state prerogatives to be overridden. With respect to this issue federalism concerns might point to a narrow construction of agency authority. In American Optometric Association v. FTC, ${ }^{46}$ a federal court of appeals observed that an FTC regulation, which it remanded for reconsideration on other grounds, may have exceeded the agency's authority because it purported to override direct regulation of opthalmic advertising by the states. ${ }^{47}$ It was possible to view the FTC rule in question, however, as an effort by a federal agency to use a very general antitrust statute as a vehicle for overriding specific state legislative policy in a field of business regulation. Such economic regulation has long been regarded as a province in which state legislatures are granted especially wide discretion. ${ }^{48}$ The direct federal interest in an OPM regulation establishing the validity of customized-liability provisions in FEHBP plans would seem to strengthen the preemption argument. Similarly, unless a state has legislated expressly on the point, ${ }^{49}$ the challenge to state prerogatives would seem slight if the only power overridden was that of state judges to rewrite private contracts.

Although it is unclear whether an OPM regulation authorizing private reforms would effectively preempt inconsistent state law, there appears to be another route by which the OPM could ensure preemption. Relying on the rule that defers to administrative interpretations of statutes, the agency could issue a regulation interpreting the FEHBP preemption statute ${ }^{50}$ to apply to customized-liability provisions in health benefits plans. Thus, the OPM regulations could be nearly as effective in authorizing private tort reform as new federal legislation.

\footnotetext{
44. See 5 U.S.C. \$ 8902 (1982).

45. See 5 U.S.C. $\$ 8913$ (a) (1982).

46. 626 F.2d 896 (D.C. Cir. 1980).

47. Id. at 910 .

48. See, e.g., Williamson v. Lee Optical Co., 348 U.S. 483 (1955).

49. See Dinong v. Superior Court, 102 Cal. App. 3d 845, 162 Cal. Rptr. 606 (1980).

50. See supra note 32 and accompanying text.
} 


\section{III}

\section{Safeguards for Federal EMployees}

The proposal to allow federal employees to enroll in customized-liability plans contemplates that the OPM would act to protect federal employees from overreaching by carriers and providers who participate in FEHBP plans. The FEHBP statute requires the OPM, in its role as middleman, to provide two types of protection for federal employees selecting from the menu of plans offered. First, the OPM must provide employees with sufficient information to enable them to exercise an "informed choice." 51 Second, the OPM has authority to prescribe "reasonable minimum standards" for both carriers and the plans they offer. ${ }^{52}$ These statutory provisions raise two questions: how federal employees should be informed of customized-liability provisions, and whether the OPM should preclude plans from modifying liability rules in certain ways.

\section{A. Disclosure}

In deciding how the content of plans with customized-liability provisions should be disclosed, one might consider precedents in the area of malpractice arbitration clauses. One precedent is found within the FEHBP itself. The Kaiser Foundation health benefits plan serving northern California contains an arbitration clause governing medical malpractice claims. ${ }^{53}$ Apparently, the OPM has interpreted its duty to enable federal employees to exercise an informed choice as requiring only that a description of the clause be included in the plan's brochure. ${ }^{54} \mathrm{~A}$ federal employee enrolling in the plan may easily fail to appreciate that he is waiving his right to a jury trial. In addition, because federal employees remain enrolled in a plan until they change plans or drop out of the FEHBP altogether and because the OPM renegotiates its contracts with carriers yearly, an employee may become subject to a provision that was not part of the plan when he originally enrolled..$^{55}$ No special provision is made for ensuring that individuals know specifically of any changes in their legal rights.

A more rigorous approach to disclosure of arbitration requirements is found in a California statute that insulates certain arbitration clauses in medical service contracts against attack on the ground that the clauses are adhesive, unconscionable, or otherwise improper. ${ }^{56}$ In order to be so insulated, a contract must contain notice, in prominent locations and in

51. 5 U.S.C. $\$ 8907$ (a) (1982).

52. 5 U.S.C. \$ 8902(e) (1982).

53. See U.S. Office of Personnel Management, Kaiser foundation Health Plan, Inc. 5 (1985).

54. Id.

55. In Dinong v. Superior Court, 102 Cal. App. 3d 845, 162 Cal. Rptr. 606 (1980), a federal employee was held to be bound by the arbitration clause that became part of his FEHBP plan after he enrolled, despite the fact that he was unaware of the clause.

56. Cal. Civ. Proc. Code $\S 1295$ (West 1982). See also Michigan Malpractice Arbitration Act, Mich. Comp. LAws ANN. $\S 600.5041-.5042$ (Supp. 1985), which creates a presumption as to the 
statutory language, of the arbitration clause. ${ }^{57}$ One California decision treated these state requirements as binding on a FEHBP plan. ${ }^{58}$ The OPM has not, however, taken the initiative to remove arbitration clauses from such state oversight. The focus here is not on the preemption issue, however, but on the disclosure requirement that the OPM might adopt.

In Madden $v$. Kaiser Foundation Hospitals, ${ }^{59}$ the court upheld an arbitration clause which was adopted after the plaintiff had enrolled in the plan and of which he claimed to have been unaware. The plaintiff was a state employee whose benefits were provided under a scheme similar to the FEHBP, and the state was held to have acted as the plaintiff's agent in negotiating the arbitration clause. ${ }^{60}$ Under agency theory, disclosure to the agent alone would seem sufficient to entitle the plan to enforce the contract against the agent's principal, even if the latter was never informed of the deal negotiated on his behalf. But this interpretation clearly is inconsistent with the goal of ensuring informed choice by government employees. Thus, the OPM should focus not only on ensuring the contract's enforceability, but also on full disclosure to those on whose behalf it negotiates. For purposes of legal analysis, however, it may be appropriate to think of the disclosure obligation as falling on the OPM, as the agent negotiating the contract on behalf of federal employees, and not on the health benefits plan itself. Under this interpretation, once the contract is made, its enforceability cannot be called into question.

While the OPM's approach of providing only for simple disclosure in the plan's brochure may be an acceptable way to inform federal employees about arbitration clauses in FEHBP plans, California's more particularized disclosure requirement appears preferable for plans that go beyond forum selection to change substantive tort rights. As suggested by Justice Tobriner in the Madden case, contractual reforms of the liability system that do more than just change the forum impose greater restrictions on consumers' traditional rights than do arbitration clauses. ${ }^{61}$ In addition, while arbitration is considered to be a "proper and usual" means of resolving medical malpractice disputes, ${ }^{62}$ clauses making substantive changes, though not necessarily improper, are certainly unusual. ${ }^{63}$ Using the California statute as a guide, the OPM might require employees enrolling in a plan with

validity of certain malpractice arbitration provisions. This presumption is apparently rebuttable. See Capman v. Harper-Grace Hosp., 96 Mich. App. 510, 294 N.W.2d 205 (1980).

57. See Cal. Civ. Proc. Code $\$ 1295(\mathrm{e})$ (West 1982). An exception is created for consumers' contracts with providers of health care on a prepaid basis, generally known as HMO's. See Cal. Civ. Proc. Code $\S 1295$ (e) (West 1982). Michigan has similar notice requirements for the contract, but does not create exceptions and also requires that a brochure be supplied to consumers who might become subject to a malpractice arbitration clause. Мich. Сomp. Laws ANN. \$§ 600.5041(6), 600.5042(7) (Supp. 1985).

58. Dinong v. Superior Court, 102 Cal. App. 3d 845, 162 Cal. Rptr. 606 (1980).

59. 17 Cal. 3d 699, 552 P.2d 1178 , 131 Cal. Rptr. 882 (1976).

60. Id at 705,552 P.2d at 1181,131 Cal. Rptr. at 885 .

61. Id. at 712,552 P.2d at 1186,131 Cal. Rptr. at 890 .

62. Id. at 706,552 P.2d at 1182,131 Cal. Rptr. at 886.

63. See supra notes $26-31$ and accompanying text. 
customized-liability provisions to sign a document that describes the plan's reforms in language approved by the agency. It would seem especially desirable that employees should not become subject to alterations in their tort rights after they enroll in a plan unless they sign a similar document. ${ }^{64}$

\section{B. Screening Customized-Liability Provisions}

It might be argued that the OPM should not screen customized-liability provisions for fairness and should instead rely solely on disclosure to prevent overreaching. Like all consumers, however, federal employees have limited expertise in health care matters ${ }^{65}$ and would benefit from the OPM's services as a purchasing agent negotiating on their behalf and protecting them against unwise choices of liability rules. The Madden court, in upholding the arbitration clause in a plan offered under a state program similar to the FEHBP, was specifically impressed by the fact that the agency running the state program had screened plans and had "parity of bargaining strength" with carriers. ${ }^{66}$ The court's view of the agency's role suggests that the OPM should approach its task not as a regulator seeking to define or dictate the best possible set of liability rules, but as an agent of federal employees charged with ensuring that the choices offered to them are ones that rational, well-informed consumers might reasonably make. Although the agency might choose to prohibit sweeping exculpatory clauses of the kind that courts have found to be against public policy, ${ }^{67}$ it might also permit such clauses if disclosure was adequate, if it was satisfied that the employees had ample supplementary financial protection, and if the employees were given a substantial price break in return for waiving their legal rights.

Although OPM oversight is indicated, there are several reasons why the agency should not be overly protective of federal employees. First, it is not at all clear that the existing tort system provides optimal protection against the financial risks of medical injury or is an ideal quality assurance mechanism. Changes in the existing tort system would not necessarily be opposed to the employees' interests. Second, the successful twenty-five year history of the FEHBP suggests that federal employees are capable of protecting their own interests as consumers when exercising choice as to medical matters. ${ }^{68}$ Third,

64. Cf. Madden v. Kaiser Found. Hosps. 17 Cal. 3d at 717-18, 552 P.2d at 1189-90, 131 Cal. Rptr. at 893-94 (Mosk, J., dissenting) (plaintiff should not be bound by malpractice arbitration provision in a group medical plan in which he enrolled under a state program, similar to the FEHBP, where provision was incorporated into plan after he enrolled).

65. The concern that a lack of expertise in health care matters places consumers at a disadvantage with providers over malpractice liability rules has been expressed both by commentators, see Danzon, An Economic Analysis of the Medical Malpractice System, 1 BEHAv. Sc1. \& L. 39, 41 (1983); Schwartz \& Komesar, Doctors, Damages and Deterrence, 298 New Enc. J. Med. 1282, 1288 (1978), and by courts invalidating agreements to modify liability rules, see cases cited supra notes 20 22 and 26-28.

66. Madden v. Kaiser Found. Hosps. $17 \mathrm{Cal}$. 3d at 711,552 P.2d at 1185, 131 Cal. Rptr. at 889.

67. See cases cited supra note 29.

68. See A. ENTHOVEn, supra note 7, at 83 ("I have heard many arguments against multiple choice and economic competition in health insurance: 'Consumers aren't capable of making such choices';. . .'They'll all take the cheapest plan, and quality will be sacrificed.' The experience of the 
federal employees are not particularly necessitous and, moreover, are probably by nature (judging from the type of employment they have selected) risk-averse individuals who would be wary of any liability-limiting provision contained in a plan. Fourth, carriers are concerned with their image and would be careful to avoid incorporating provisions that suggest that they offer only "second-rate" coverage or inadequate deterrence against poor quality medical care. ${ }^{69}$

The most important reason for avoiding excessive agency interference, however, is to increase the likelihood that private reform of liability rules will be attempted. Excessive screening of customized-liability provisions would inhibit private reform by increasing costs and uncertainty, by restricting the types of reforms that could be proposed, ${ }^{70}$ and by signaling to the private sector that government continues to have the final word. ${ }^{71}$ To further improve the climate for private reform, the FEHBP initiative should expressly insulate customized-liability provisions from attack in the courts once they have survived the OPM screening and have been freely chosen by consumers to whom the prescribed disclosure has been made.

\section{IV}

\section{Practical Problems}

Simply permitting private reform of malpractice liability rules within the FEHBP will not guarantee that such reform will occur. The development of a health benefits plan that alters the responsibilities of providers and the rights of federal employees necessarily depends upon the creation of a three-way contractual relationship between providers, a carrier, and federal employees. The carrier offering the plan is the intermediary. The carrier must first get providers to agree that an altered set of liability rules will govern their legal relationship with federal employees who enroll in the plan. The carrier then must convince federal employees that it is in their interest to enroll in a plan governed by such rules.

This general scenario raises two questions. The first is what types of carriers participating in the FEHBP can best develop contractual relationships with providers. The second question is how a carrier can entice providers and federal employees to participate in such a plan. In general, some practical difficulties exist that raise questions about the likelihood that significant private initiatives will be taken, even if the federal government invites them. Nevertheless, even if deviations from established patterns are initially

\footnotetext{
FEHBP shows that these, and most of the other, arguments against such competition are not supported by experience.").

69. Interview with Ron Rabbu, member of the OPM's Office of Insurance Programs, Program Planning and Evaluation Division, in Washington, D.C. (Nov. 21, 1984).

70. The agency might well impose many restrictions as a result of a risk-averse strategy or in the pursuit of egalitarian goals. See C. Havighurst, supra note 13, at 398-99, $401-04$.

71. Cf. id. at 387 (health care industry tends to await government's decisions as to what course reform should take since government has a continued presence in the health care sector as a "regulator, major purchaser, and indecisive architect").
} 
infrequent, a great deal might be learned from the occasional initiatives, which others might then be stimulated to emulate. In addition, placing responsibility on the private sector seems generally in keeping with other recent developments in federal health policy. ${ }^{72}$

\section{A. Developing Contractual Relationships Between Carriers and Providers}

One group of FEHBP carriers are the traditional fee-for-service carriers. These carriers offer plans that pay for provider services on the basis of "usual and customary" fees or a fee schedule. The traditional fee-for-service carriers participating in the FEHBP include: Blue Cross and Blue Shield, whose Federal Employees Program runs the government-wide Service Benefit Plan; ${ }^{73}$ Aetna life \& Casualty, which runs the government-wide Indemnity Benefit Plan; ${ }^{74}$ and various employee organizations, which run plans tailored to the needs of particular groups that are spread across the country or around the world, such as foreign service personnel. ${ }^{75}$ Of these traditional fee-forservice carriers, only Blue Cross and Blue Shield and a few employee organizations rely significantly upon contracts with providers to obtain services for plan subscribers. ${ }^{76}$ The other traditional carriers, unless they change their methods of operation, are in a poor position to develop plans that alter malpractice liability rules. ${ }^{77}$

Even though Blue Cross and Blue Shield and some employee organizations currently maintain contracts with providers, modifying these carriers' plans in order to change malpractice liability rules might appear to be a hopeless task. Because these plans generally offer the same packages to federal employees across the country, ${ }^{78}$ it might appear that the carriers would have to get all of their providers across the country to agree to a given liability reform. A recent development in the FEHBP, however, demonstrates that plans offered by traditional fee-for-service carriers do not have to be changed on a nationwide scale. In the near future, an employee organization plan that services federal employees across the country may offer its federal employees in, for example, the Baltimore-Washington area the option of

72. Havighurst, Private Reform of Tort-Law Dogma: Market Opportunities and Legal Obstacles, LAw \& Contemp. Probs., Spring 1986, at 143.

73. See 5 U.S.C. $\$ 8903$ (1) (1982).

74. See 5 U.S.C. \$ 8903(2) (1982).

75. See 5 U.S.C. $\$ 8903(3)(1982)$.

76. Interview with Ron Rabbu, supra note 69. Under the contracts, providers agree to accept what the carrier pays for various services as payment in full.

77. The carriers, which do not rely on contracts with providers, only agree with subscribers to pay certain amounts either to the subscribers or directly to the service providers. The subscriber is responsible for any difference between the amount charged for the service and what the carrier has agreed to pay. Interview with Kenneth Lease, member of the OPM's Office of Insurance Programs, Program Planning and Evaluation Division, in Washington, D.C. (Nov. 21, 1984).

78. Telephone interview with Ron Rabbu, member of the OPM's Office of Insurance Programs, Program Planning and Evaluation Division (Jan. 7, 1985). The Blue Cross and Blue Shield Plan must have two levels of benefits, 5 U.S.C. $\$ 8903(1)(1982)$, and employee organization plans may have two options, see 5 C.F.R. $\$ 890.201(\mathrm{~b})(3)$ (1984) (authorizing all plans to have two options). Currently, however, the same options generally are offered nationwide. Telephone interview with Ron Rabbu, supra. 
seeking care through a so-called "preferred provider organization" (PPO). 79 Because a PPO is usually constituted through provider contracts and functions on a local scale, ${ }^{80}$ it might be utilized by traditional fee-for-service carriers to offer federal employees an alternative source of health care under a different set of malpractice liability rules. Indeed, the prospect of some malpractice relief might be powerful inducement for physicians and hospitals to join a PPO and to grant a discount to consumers willing to give up some of their tort rights.

Health maintenance organizations (HMO's) constitute a separate group of FEHBP carriers, operating what are called "comprehensive medical plans." In contrast to fee-for-service plans, which reimburse providers or patients for each service rendered, these plans offer all needed medical services to federal employees for a fixed, prepaid amount. ${ }^{81}$ Health maintenance organizations operate on a local scale and fall into three categories-“staff model" HMO's, “group-practice prepayment plans," 82 and "individual-practice prepayment plans." 83 Staff model HMO's directly employ salaried physicians. In grouppractice HMO's, medical services are rendered by a physician group that practices in a common center or centers and receives all or part of its professional income from a prepaid fund. ${ }^{84}$ Individual-practice HMO's contract with individual physicians and physician groups to provide services in return for compensation that can take various forms. ${ }^{85}$ Because all types of HMO's are local in nature and are based on contractual relations, these organizations might be able to develop customized rules governing malpractice liability.

79. Telephone interview with Ron Rabbu, supra note 78.

80. Knowledge of some other facts about PPO's may be useful. See generally Am. MediCal Ass'N, Preferred Provider Organizations 3-9 (1983). Although there is not a "typical" PPO, all PPO's contract with providers to render services to a defined population of subscribers. Unlike HMO's, PPO's reimburse these "preferred providers" on a fee-for-service basis, where the fees are agreed upon in advance. The fees agreed upon often are at a discount of up to $15 \%-20 \%$ from usual charges. The discount, in time, can be passed on to subscribers. In contrast with members of HMO's, PPO subscribers may receive services from non-preferred physicians and do not have to shoulder the entire cost of these services. Financial incentives generally are built into PPO's, however, to encourage subscribers to use preferred providers.

81. See 5 U.S.C. \$ 8903(4) (1982). Exactly which organizations may offer comprehensive medical plans should be clarified. As noted earlier, the term "health maintenance organization" generally refers to an organization offering prepaid health plans. See supra note 57. The FEHBP statute, however, appears to specify that comprehensive medical plans may only be run by organizations that meet the requirements of a federal statute that controls which organizations qualify as HMO's for the purpose of receiving federal assistance. See 5 U.S.C. § 8902(l) (1982) (referring to 42 U.S.C. $\$ 300 \mathrm{e}-9$ (d) (1982)). Nevertheless, the OPM contracts with any organization that simply meets applicable state law requirements for HMO's. Telephone interview with Kenneth Lease, member of the OPM's Office of Insurance Programs;: Program Planning and Evaluation Division (Jan. 7, 1985); Telephone interview with Ron Rabbu, supra note 78.

82. See 5 U.S.C. $\$ 8903(4)$ (A) (1982).

83. See 5 U.S.C. $\$ 8903(4)$ (B) (1982).

84. 5 U.S.C. $\$ 8903(4)(A)(1982)$.

85. 5 U.S.C. $\$ 8903$ (4) (B) (1982). The contracts provide that the physician will accept payment provided by the plan as full payment for covered services. Id. 


\section{B. Inducing Federal Employees and Providers to Participate in a} Customized-Liability Plan

A plan that enables providers to reduce their costs associated with malpractice liability and explicitly to pass some of these savings on to enrollees would appear to have the best chance of enticing both federal employees and providers to participate. Nevertheless, a federal employee might agree to a liability reform even without receiving an identifiable benefit in return. For example, many federal employees have enrolled in the Kaiser Foundation plan which requires an enrollee to arbitrate any malpractice claim but which, apparently, offers no concession in exchange. ${ }^{86}$ In order to interest federal employees in reforms that go beyond arbitration and alter substantive liability rules, however, it may be essential to offer specific inducements. ${ }^{87}$

The two areas in which a customized-liability plan might produce savings in provider costs are malpractice insurance costs and defensive medicine costs. ${ }^{88}$ It may be difficult for providers to realize savings in malpractice insurance costs. Because federal employees are likely to constitute only a small percentage of the practice of a given provider, a liability insurer may not see fit to lower premiums to reflect any marginal savings produced by an alteration of liability rules applicable to these patients alone. Under most plan/provider contracts, the provider agrees to treat all patients covered by the carrier, not just federal employees enrolled in the carrier's FEHBP plan. ${ }^{89}$ Except in a few staff-model and group-practice HMO's, providers are not

86. See supra note 53 and accompanying text.

87. Interview with Kenneth Lease, supra note 77; Interview with John McCart, member of OPM's Office of Insurance Programs, Comprehensive Plans Division, in Washington, D.C. (Nov. 21, 1984); Interview with Ron Rabbu, supra note 69.

88. Carriers probably would want to pass on savings in the form of reduced cost sharing or expanded coverage rather than in the form of reductions in premiums, since the federal government would share such reductions with federal employees. Interview with Ron Rabbu, supra note 69; see supra note 6.

HMO's that desire to qualify for federal assistance would be precluded, however, from passing on savings only to federal employees and not to other members enrolled in the organizations. An HMO, in order to qualify for federal assistance, must offer all of its members the same package of services at rates fixed under a "community rating system." See 42 U.S.C. $\$ 300 \mathrm{e}(\mathrm{b})(1)$ (1982). Such a system may classify members into groups and assign a different rate for each group, but such a classification may only be "based on factors which the [HMO] determines predict the differences in the use of health services by the [members] in each class." 42 U.S.C. $\$ 300 \mathrm{e}-1(8)(\mathrm{C})$ (i) (1982). An exception to the classification rule allows different rates for an HMO's members who enrolled pursuant to a contract between a federal government authority and the HMO. But this exception is specifically voided in the case of the FEHBP. See 42 U.S.C. \$ $300 \mathrm{e}-1$ (8)(D) (1982).

Thus, it may be desirable to amend this federal HMO legislation in order to permit HMO's receiving federal assistance to offer FEHBP health benefits plans that pass savings on to enrolling federal employees who agree to a malpractice liability reform. The absence of such an amendment, however, would not mean that HMO's participating in the FEHBP could not pass on such savings. As noted earlier, the OPM does not require HMO's offering health benefits plans to be qualified for federal assistance; simply meeting applicable state requirements is sufficient. See supra note 81. In addition, many HMO's find that whether they qualify for federal assistance is inconsequential because such assistance currently is meager.

89. Interview with Ron Rabbu, supra note 69. 
limited to treating plan subscribers but may treat other patients as well.90 Significant difficulties would be encountered in estimating the reduced liability exposure from a customized-liability provision affecting a variable fraction of a provider's patients.

Another barrier to the realization of savings from modified malpractice liability rules is the reluctance of malpractice insurers to vary the premiums of individual physicians on the basis of their individual claims experience. ${ }^{91}$ This general insurance industry practice is not an absolute barrier, however. Some providers' insurance rates are affected by their individual records, while other providers, such as some hospitals and HMO's, self-insure to some extent. ${ }^{92}$ In addition, an FEHBP initiative of the kind considered in this note could motivate insurers to reward providers who obtain voluntary relief from malpractice suits. ${ }^{93}$

Although a carrier might anticipate lower costs if customized-liability provisions reduced pressures to practice defensive medicine, these savings may be hard to realize. Because federal employees under special liability rules would undoubtedly represent only a small part of the practice of most providers, providers may find it impractical or undesirable to change their practice style when treating these individuals. ${ }^{94}$ Alternatively, if a plan should induce a change in practice style, the benefits of that change may be shared by other carriers covering patients of that provider. Some HMO's, however, might be able to capture and pass on savings from the elimination of defensive practice.

\section{V}

\section{Facilitating Private Reform of Liability Rules in Other Federal Programs}

Federal health care financing programs other than the FEHBP could also be modified to permit private reform of malpractice liability rules. One such program is Medicare, ${ }^{95}$ an entitlement program under which the federal government pays participating providers for rendering medical services to the aged and disabled. ${ }^{96}$ Traditionally, Medicare's strong orientation toward

90. While physicians participating in some group-practice HMO's may not treat consumers who are not members of the HMO, physicians participating in many other plans may treat consumers who are not parties to those arrangements. See American Medical Association, supra note 80, at 6.

91. Schwartz \& Komesar, supra note 65, at 1287.

92. Telephone interview with Elton Stone, Risk Manager for Kaiser Foundation Corporation (Dec. 5, 1984).

93. Id.

94. If providers participating in HMO's or PPO's can realize savings in the costs of defensive medicine, however, HMO's and PPO's appear to be in a good position to negotiate with these providers to alter their style of practicing medicine. HMO's and PPO's generally have mechanisms in place for reviewing the level of care rendered by their providers. See Fox \& Weismann, Introduction to Attorneys \& Physicians Examine Preferred Provider Organizations at vii (J. Waxman ed. 1984).

95. 42 U.S.C. $\$ \S 1395-1395 z z$ (1982 \& Supp. I 1983).

96. See 42 U.S.C. $\$ 1395 \mathrm{c}$ (1982). 
reimbursing providers on a fee-for-service basis ${ }^{97}$ inhibited participation by HMO's in the program. Under 1982 legislation, however, the federal government will now pay a set amount to an approved HMO on behalf of an enrolled Medicare beneficiary. ${ }^{98}$

The HMO amendment to Medicare creates an incentive for a Medicare beneficiary to compare HMO's. The competitive arena thus created is a potential site for encouraging HMO's-perhaps by explicit legislation-to offer beneficiaries a chance to economize by agreeing to an alteration of prevailing liability rules. Safeguards similar to those discussed in section III, above, could be implemented to protect beneficiaries. Reform need not stop here, however. The arena of competition could be enlarged by creating a "voucher" system modeled after the FEHBP.99 Such a voucher system would expand upon the concept underlying the new HMO option by providing all Medicare beneficiaries with a fixed public contribution that could be applied toward the purchase of any approved private health care plan. The carriers of these plans could in turn be allowed by the Health Care Financing Administration to offer beneficiaries customized liability rules under safeguards similar to those suggested above.

Another potential area for facilitating private reform of liability rules is the CHAMPUS ${ }^{100}$ program, which enables certain military personnel and their dependents to obtain health care from private providers. ${ }^{101}$ The statute creating the program commands the Secretary of Defense to "contract . . . for medical care for [beneficiaries of CHAMPUS] under such insurance, medical service, or health plans as he considers appropriate." 102 This vague language has been used to create a program by which the federal government acts as an insurance carrier for CHAMPUS beneficiaries. ${ }^{103}$ Although most CHAMPUS beneficiaries do not choose among competing private health plans, a recent experiment has allowed beneficiaries in certain geographical areas to enroll in HMO's with the benefit of a government subsidy designed to encourage them to compare costs. ${ }^{104}$ This experiment is limited in scale, ${ }^{105}$ but it may signal a movement toward a kind of voucher system and the creation of a competitive arena in which private health plans can experiment with modifications of liability rules.

97. See 42 U.S.C. § $1395 \mathrm{cc}$ (Supp. I 1983).

98. See 42 U.S.C. $\$ 1395 \mathrm{~mm}$ (1982 \& Supp. I 1983). Actually, payments may only be made to an "eligible organization," but this term is defined to encompass most HMO's. See 42 U.S.C. $\S 1395 \mathrm{~mm}$ (b) (Supp. 1985).

99. See Ginsburg, Medical Vouchers and the Procompetitive Strategy, 1 Health Afr. 39 (1971).

100. 10 U.S.C. $\$ \$ 1071-1093$ (1982 \& Supp. II 1984).

101. See 10 U.S.C. $\$ \$ 1079,1086$ (1982 \& Supp. II 1984).

102. 10 U.S.C. $\S 1079$ (a) (Supp. II 1984); see also 10 U.S.C. $\S 1086$ (a) (Supp. II 1984) (referring to $\S 1079(\mathrm{a}))$.

103. Interview with Morris Jones of the Office of the Civilian Health and Medical Program of the Uniformed Services (CHAMPUS) (Jan. 9, 1985). The "plan" that the federal government offers CHAMPUS beneficiaries is modeled after a Blue Cross and Blue Shield plan. Id.

104. Id.; see also 10 U.S.C. § 1092(a)(1)(F) (Supp. II 1984).

105. Telephone interview with Morris Jones, supra note 103. 
A final way for the federal government to encourage private reform would be to amend the HMO Act. ${ }^{106}$ In general, the HMO Act specifies requirements that organizations must meet in order to qualify for certain statutory benefits. Nothing in the Act specifically prohibits federally qualified HMO's from entering into customized-liability agreements with their enrollees. ${ }^{107}$ Nevertheless, legislation amending the act to authorize such provisions in HMO contracts would increase the likelihood of experimentation with such agreements.

\section{VIII}

\section{Conclusion}

This note proposes that the FEHBP permit private carriers to offer federal employees the opportunity to enroll in health benefits plans that modify the arguably unsatisfactory tort rules governing medical malpractice. The OPM would act on behalf of federal employees by ensuring full disclosure of the changes in legal rights proposed and by screening out unconscionable proposals. In addition to providing these safeguards, the OPM should declare that plan reforms adopted under its auspices are not to be denied enforcement by state or federal courts. Although congressional action is probably not necessary to effectuate this proposal, legislation might be desirable as a way of signalling the OPM, the private sector, and the courts that this path to private reform is available and has the government's approval.

The proposal offered here is a limited one that, at best, could affect only a small portion of the population. Nevertheless, it offers an opportunity for Congress, which has expressed interest in the problem, to take a constructive step toward solving the malpractice impasse. By steering a middle course the federal government does neither too little nor too much, and gives leadership to the states while staying well within its legitimate province for federal action on an issue that is primarily a state responsibility. Moreover, by adopting the proposal the federal government would send a clear signal to private interests concerning their opportunity and responsibility to develop reforms of malpractice liability rules. Although the modest measure suggested here may not respond adequately to the desire of some for Congress to do something dramatic about the emerging malpractice crisis, it might serve to open up the private sector as a new avenue to reform of liability rules.

106. 42 U.S.C. $\$ \S 300 \mathrm{e}$ to $300 \mathrm{e}-17$ (1982).

107. Nevertheless, the "community rating system" requirement of the HMO Act would present an obstacle to federally qualified HMO's that want to pass on savings realized through liability limiting agreements. See supra note 88 . 
